EESTI NSV TEADUSTE AKADEEMIA TOIMETISED. V KOIDE BIOLOOGILINE SEERIA. 1956, NR. 3

ИЗВЕСТИЯ АКАДЕМИИ НАУК ЭСТОНСКОЙ ССР. ТОМ V СЕРИЯ БИОЛОГИЧЕСКАЯ. 1956, № 3

\title{
ПРЕДВАРИТЕЛЬНЫЕ ДАННЫЕ О ТЕРМОФИЛЬНОМ ВОЗБУДИТЕЛЕ ФИКСАЦИИ АТМОСФЕРНОГО АЗОТА (THERMOBACILLUS AZOTOFIGENS RAHNO ET TOHVER SP. N.)
}

\section{В. И. ТОХВЕР}

До последнего времени в распоряжении микробиологии было недостаточно конкретного материала для положительного решения вопроса о существовании термофильного фиксатора молекулярного азота воздуха $\left({ }^{3,4}\right)$. Известно только сообщение $Г$. Прингсгейма $\left({ }^{7}\right)$, относящееся к 1911 году, в котором указывается, что автору удалось получить путем посева из почвы сада Химического института Берлинского университета на безазотистой среде в условиях инкубации при $61^{\circ} \mathrm{C}$ прибыль азота от 3,0 до 6,2 мг на 1 г израсходованного энергетического материала (глюкозы). Он получил процесс фиксации атмосферного азота на среде Виноградского для азотоусвойтелей при добавлении к ней большого количества почвенной вытяжки. Культуры Прингсгейма были склонны инактивироваться - развитие прекращалось обычно при наличии в среде еще около $50 \%$ неизрасходованного сахара. Прингсгейм не выделил, к сожалению, возбудителя процесса в чистую культуру, в связи с чем не мог дать-и его описания.

В определителях-справочниках $\left({ }^{2,3}\right)$ термофильный возбудитель фиксации атмосферного азота пока не описывался, и процесс термофильного азотоусвоения находится под сомнением. Это тем более понятно, что попытки открыть азотфиксацию при повышенных температурах, предпринятые некоторыми другими исследователями $\left({ }^{4,5}\right)$, оказались безуспешными.

Установление термофильного азотоусвоения. 16 марта 1955 года нам удалось получить из промерзшей полевой почвы колхюза им. И. В. Мичурина Харьюского района ЭССР развитие неизвестной культуры микроба на безазотистой среде (Эшби-агаре) в условиях культивирования при температуре $60^{\circ} \mathrm{C}$. Пробы почвы были взяты на глубине $10 \mathrm{~cm}$ от поверхности. Позже удалось получить развитие аналогичной культуры микроба из почвенных проб тех же почв, взятых на глубине 5 см. Данные почвы дерново-карбонатные, с тонким пахотным горизонтом, с рН около 7,5 .

Выделенный таким образом микроб привлек к себе интерес как термофильный азотфиксатор.

Для выращивания чистой культуры выделенного микроба были произведены пересевы в аэробных условиях на Эшби-агар, как и при начальной культуре. Оказалось, что в таких условиях пересевы к успеху не 
приводят - микроб в дальнейшем не развивался. Казалось, что дальнейшая работа над микробом невозможна, но затем нам удалось выяснить, что для своего развития микроб неизбежно требует наличия в питательной среде некоторого количества пөчвенной вытяжки. Однако первые наши опыты с добавкой почвенной вытяжки к питательной среде (Эшби или Виноградского) не дали вполне удовлетворительного результата - развитие микроба носило весьма случайный характер и происходило не во всех опытных сосудах. При наблюдениях за культурой микроба можно было заметить, что его рост и развитие происходили более успешно в случаях, когда из приготовленной в колбе среды использовался придонный слой, содержащий больше мела, чем верхние слои. Это обстоятельство навело нас на мысль, что успех культивирования микроба зависит отчасти от реакции среды. Ведь сам микроб был выделен из почвы, $\mathrm{pH}$ который составляет $7,5-7,9$, в то время как испытанные нами среды имели реакцию в интервале $\mathrm{pH} 6,5-7,0$. Когда мы изготовили буферные среды с постоянной реакцией, результаты заметно улучшились. Было ясно, что микроб требует специальной среды. Нам удалось составить соответствующую среду, на которой успех культивирования микроба был достигнут. Минеральная часть этой среды для жидких культур имеет состав: $\mathrm{K}_{2} \mathrm{HPO}_{4}-0,24 \%, \mathrm{KH}_{2} \mathrm{PO}_{4}-0,01 \%, \quad \mathrm{MgSO}_{4}-0,02 \%, \mathrm{NaCl}-$ $0,02 \%, \mathrm{FeSO}_{4}$ и $\mathrm{MnSO}_{4}$ - следы, мел-0,5\%. Для агаровых сред все минеральные соли вносились в двойном количестве. Энергетического материала вносили от 0,5 до $2 \%$. Все указанные компоненты растворялись в 900 мл дестиллированной воды, затем добавлялось 25-50 мл почвенной вытяжки, 10 мл отвара дрожжей, 1 мл смеси микроэлементов (по М. В. Федорову) и общий объем раствора доводился дестиллированной водой до 1000 мл. Стерилизация среды производилась в автоклаве при давлении 0,5 атмосфер в течение 30 мин.

Указанной средой мы пользовались во всех дальнейших опытах.

Первые опыты по установлению способности микроба к усвоению атмосферного азота были проведены на жидких культурах без учета израсходованного сахара. Эти опыты показали, что при температуре $50^{\circ} \mathrm{C}$ и продолжительности опыта в 48 часов прибыль азота на 1 г добавленного сахара составляла в среднем 2,74 мг. Эти данные оказались настолько интересными и убедительными, что привели нас к необходимости заняться дальнейшим изучением полученного микроба. Результаты. этих исследований кратко изложены ниже.

О морфологии микроба. После выделения чистой культуры термофильного возбудителя фиксации атмосферного азота оказалось, что мы имеем дело с палочковидным спорообразующими, т. е. с бациллярными формами. Вегетативные клетки имеют размеры в длину от 5 до $7-10 \mu$ и в поперечнике от 0,5 до $1,2 \mu$. Клетки молодых культур более короткие, с возрастом они вытягиваются. Клетки тупоконечные со слегка округленными концами, в молодом возрасте (24-48 час.) перитрихально снабжены многочисленными жгутиками и подвижны. Микроб склонен к образованию цепочек. Вегетативные клетки хорошо окрашиваются в спиртовом растворе фуксина.

Микроб положительно окрашивается по Граму. В среде с содержанием сахара переходит к спорообразованию с четвертого-пятого дня инкубации. Спора терминальная, в большинстве случаев имеет овальную форму, в поперечнике от 1,5 до 2 раз крупнее, чем вегетативная клетка. Қапсул нет, клостридиальных форм также не наблюдается.

На агаровых средах развитие культуры начинается с появления колоний, которые первоначально имеют вид слизистых капель. В 1-2-дневных культурах колонии маленькие, большей частью с круглым основа- 
нием, всегда с ровными краями, немного выпуклые, беловато-прозрачные. Слизь культуры имеет в данном возрасте более жидкую консистенцию. Начиная с 3-4 дня культуры правильный вид колоний исчезает; колонии разрастаются во всех направлеєниях по поверхности агарового слоя, сливаются, и наконец вся поверхность среды в чашке Петри покрывается беловатой, тягучей, прилипающей, вязкой слизью, имеющей неровную внешнюю поверхность. К этому времени колонии несколько въедаются в питательную агаровую среду.

В жидких культурах определить начало развития микроба можно по помутнению жидкости и выделению пузырьков газа. Образование спор начинается здесь обычно на один день позже, чем на агаровых средах. В жидкой культуре с необновляемым составом развитие микроба кончается в условиях инкубации при температуре $45-50^{\circ} \mathrm{C}$ на $8-10$ день. Под микроскопом в капельке такой культуры можно видеть почти одни споры. К этому времени в культуре образуется слой колеблющейся вязкой слизи.

О физиологии микроба. Изучаемый нами микроорганизм аэробен. В жидких культурах его развитие и азотфиксирующая способность выражены сильнее при условии хорошей аэрации (при взбалтывании 3 раза в день в течение 10 минут).

Микроб способен использовать разные углеводы в качестве энергетического материала. Наши опыты дали положительные результаты при использовании для приготовления сред глюкозы, сахарозы, обычного сахара, мальтозы и декстринов. Из солей органических кислот микроб способен использовать соли лимонной и винной кислот. Мы получили развитие культуры, хотя и слабое и с меньшим образованием слизи, на средах с небольшими дозами $(0,2-0,5 \%)$ аспарагина. В то же время нам не удалось получить развития микроба на мясопептонных средах, а также на средах с нитратами $(0,1 \%)$. Среды без органического вещества роста не дали, следовательно, об углеродной автотрофии не может быть речи.

Судя по силе развития микроба, наилучшими энергетическими материалами для него следует считать сахарозу и обычный сахар. Развитие, рост, полнота использования энергетического материала и продуктивность азотоусвоения возрастают, если пользоваться ниизими концентрациями углеводов $(0,5-1,0 \%)$. В качестве нейтрализирующего питательную среду вещества хорошие результаты в отношении развития культуры микроба дает использование неочищенного мела.

Заметное усиление развития и роста микроба происходит в условиях инкубации при повышенных температурах, начиная с $40^{\circ} \mathrm{C}$. При данных температурах лаг-фаза продолжается не больше $18-24$ часов. Культура сравнительно быстро заканчивает свое развитие (как уже указывалось выше, на восьмой-десятый день). При этом культура не всегда успевает полностью израсходовать прибавленный в среду сахар. Известную роль в этом отношении играют также такие факторы как аэрация, концентрация энергетического материала и количественное соотношение между последней и почвенной вытяжкой, но значение этих и других возможных факторов пока еще мало изучено.

Чтобы найти для исследуемого микроба температурные кардинальные точки, мы провели его инкубацию с температурными интервалами в $5^{\circ}$, начиная с комнатной температуры $\left(18-20^{\circ} \mathrm{C}\right)$ и до $65^{\circ} \mathrm{C}$. Наилучшее развитие наблюдалось при $45-50^{\circ} \mathrm{C}$. При комнатной температуре и при $65^{\circ} \mathrm{C}$ развития не наблюдалось. Температурный минимум лежит около $25^{\circ} \mathrm{C}$, максимум - между $60-65^{\circ} \mathrm{C}$. Следует указать, что опыты для установления отношения микроба к температурным влияниям были про- 
ведены только на нашей среде с внесением углеводов в качестве энергетического материала. Возможно, что на других средах положение температурных точек будет несколько отличаться от приведенных. Нельзя сомневаться также и в том, что температурные кардинальные точки зависят от условий среды. Например, наши опыты на средах с различными значениями $\mathrm{pH}$ (регулирование $\mathrm{pH}$ производилось путем изменения в среде количественного соотношения между одно- и двухзамещенными фосфатами), показали, что при более низких значениях $\mathrm{pH}(6,8-7,0)$ температурный оптимум лежит также несколько ниже, чем при более высоких, к тому же оптимальных, значениях реакции среды $(\mathrm{pH}=7,5)$. В этом мы видим также и одну из причин того, что первые пересевы на Эшби-агаре дали отрицательные результаты.

Об отношении микроба к температурным влияниям мы судили по визуально устанавливаемой интенсивности роста. На основании этих данных описываемый микроб следует отнести, - исходя из принципов классификации Моррисона и Теннера $\left({ }^{6}\right)$, - к термотолерантным формам термофильных микроорганизмов, а по классификации Имшенецкого $\left(^{1}\right)$ - к переходным формам между группами эвритермных и термотолерантных микробов. Результаты наших опытов показывают, что микроб может развиваться в относительно узком диапазоне значений $\mathrm{pH}$ среды. Развитие культуры микроба не наблюдалось уже при снижении $\mathrm{pH}$ среды до 6,5, а также при повышении $\mathrm{pH}$ среды до 8,3.

В жидкой культуре на нашей среде микроб образовывает кислоты, если энергетическим материалом являются сахара. Для титрования 10 мл такой питательной среды с $2 \%$ содержанием сахара без внесения в него микроба требуется израсходовать в среднем 2,32 мл $0,02 \mathrm{n} \mathrm{H}_{2} \mathrm{SO}_{4}$, используя в качестве индикатора розоловую кислоту. Для такого же титрования 10 мл питательной среды, взятой из-под 7-дневной культуры, уже надо было израсходовать 1,20 мл 0,02 n NaOH. Ha 1 г сахара образовалось, следовательно, 3,51·10-4 г-экв титруемой кислоты. Изменения $\mathrm{pH}$ были в этом опыте сравнительно небольшие, что объясняется воздействием на среду добавленного мела - электрометрическое измерение показало падение $\mathrm{pH}$ с 7,48 до 6,95 . Можно предполагать, что причиной того, что культура в некоторых случаях заканчивает свое развитие до полного израсходования находящегося в среде сахара, является изменение реакции среды в неблагоприятную сторону.

По способности усваивать молекулярный атмосферный азот наш микроб стоит близко к Clostridium Pasteurianum, несколько даже превосходя последний. Для опытов такого рода служили жидкие культуры в 250-мл эрленмейеровских колбах, в каждую из которых вносилось 100 мл питательной среды. Инкубация производилась при температуре $50^{\circ} \mathrm{C}$. Продолжительность инкубации - 5 дней. Варианты опытов отличались по концентрациям энергетического материала (сахарозы) в питательной среде (1 и 2\%). Чтобы установить влияние аэрации, культуры в одной группе колб взбалтывались по 3 раза в день в течение 10 минут каждый раз, другая группа колб не взбалтывалась. Для контроля служили такие же колбы без заражения. Повторность оныта была трехкратная. Средние результаты опыта приведены в таблице 1 .

В конце опыта мы определили количество общего азота по Кьельдалю во всем объеме питательной среды, в контрольных колбах и в 80 мл из опытных колб. В остальных 20 мл питательной среды опытных колб мы определили колинество неизрасходованного сахара по Бертрану. Все данные были затем пересчитаны на полный объем питательной среды колб (100 мл). 
Как видно из таблицы, влияние лучшей аэрации проявляется прежде всего в усилении активности общего азотоусвоения. В продуктивности процесса при пересчете на 1 г израсходованного энергетического материала это влияние сказывается в меньшей мере, так как без дополнительной аэрации среды более низкому уровню азотоусвоения соответствует и меньшее количество использованного сахара.

Таблица 1

\begin{tabular}{|c|c|c|c|c|c|c|c|c|}
\hline \multirow[b]{2}{*}{ 卢 } & \multirow{2}{*}{ 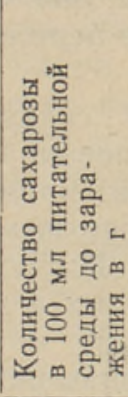 } & \multirow[b]{2}{*}{ 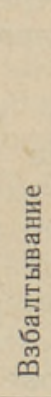 } & \multicolumn{2}{|c|}{$\begin{array}{c}\text { Количество } \\
\text { общего азота в } \\
\text { питательной среде } \\
\text { в конце опыта в мг }\end{array}$} & \multirow{2}{*}{ 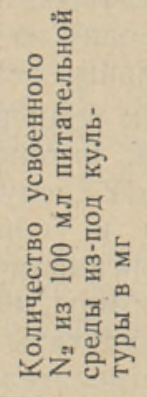 } & \multirow{2}{*}{ 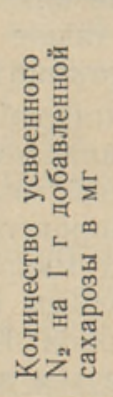 } & \multirow{2}{*}{ 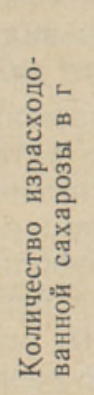 } & \multirow{2}{*}{ 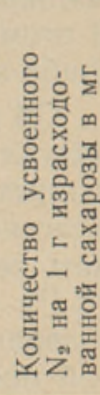 } \\
\hline & & & 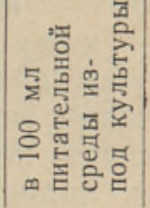 & 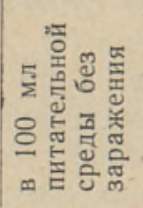 & & & & \\
\hline $\begin{array}{l}1 \\
2\end{array}$ & $\begin{array}{l}1,0 \\
1,0 \\
2,0 \\
2,0\end{array}$ & $\frac{+}{+}$ & $\begin{array}{l}4,98 \\
3,91 \\
6,60 \\
5,12\end{array}$ & $\begin{array}{l}0,86 \\
0,82 \\
1,12 \\
1,08\end{array}$ & $\begin{array}{l}4,12 \\
3,09 \\
5,48 \\
4,04\end{array}$ & $\begin{array}{l}4,12 \\
3,09 \\
2,74 \\
2,02\end{array}$ & $\begin{array}{l}0,913 \\
0,728 \\
1,697 \\
1,403\end{array}$ & $\begin{array}{l}4,51 \\
4,24 \\
3,22 \\
2,88\end{array}$ \\
\hline
\end{tabular}

\section{Заключение}

Получен процесс азотоусвоения при повышенных температурах и выделен в чистую культуру возбудитель этого процесса, которого в дальнейшем будем называть Thermobacillus azotofigens Rahno et Tohver sp. n. Бацилл представляет собой аэроб. Размеры клетки 5 до 7 (10) × 0,5 до $1,2 \mu$. В молодых культурах клетки более короткие (фото 1), с возрастом вытягиваются (фото 2 и 3). Концы клеток тупые, слегка округленные. Жгутики расположены перитрихально. Молодые клетки (24-48 час.) подвижны. Спорообразование происходит начиная с четвертого-пятого дня инкубации. Терминальная, овальная спора в поперечнике 1,5-2 раза крупнее, чем вегетативная клетка (фото 4). Капсуль не образует. На нашей агаровой среде (см. стр. 281) колонии появляются в течение $18-24$ часов в виде бесцветных слизистых капель, которые начиная с 3-4 дня культивирования разрастаются, сливаются, пока вся питательная среда будет покрыта беловатой, вязкой слизью. В жидкой культуре - муть и слизь. По Граму красится положительно. Микроб способен использовать разные углеводы и некоторые соли органических кислот, но наилучшим энергетическим материалом является для него обычный сахар. В мясопептонных средах и в средах с нитратами не растет. Температурный оптимум составляет $45-50^{\circ} \mathrm{C}$, минимум - около $25^{\circ} \mathrm{C}$, максимум - около $65^{\circ} \mathrm{C}$. Возможные границы $\mathrm{pH}$ от 6,5 до 8,3 (оптимум $-7,5$ ). В среде с сахаром образует кислоты. Усваивает молекулярный азот в количестве от 2,88 до 4,51 мг на 1 г израсходованного сахара. 


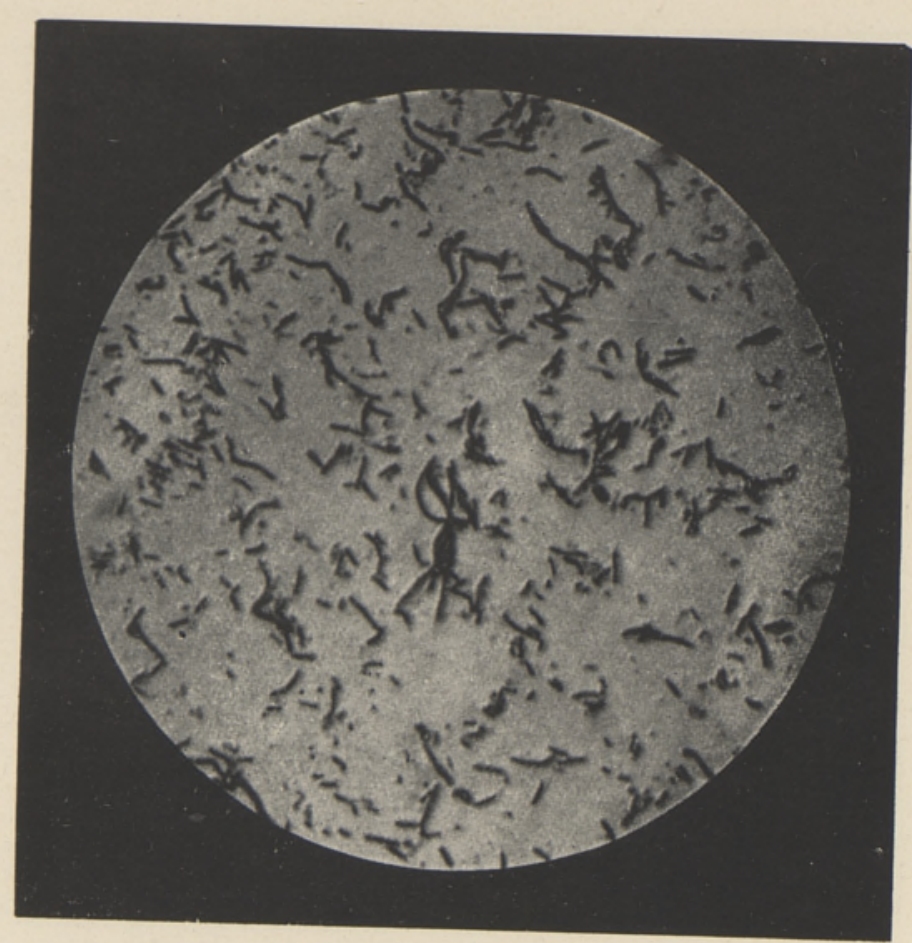

Фото 1. 30-часовая культура Thermobacillus azotofigens.

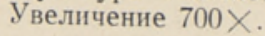

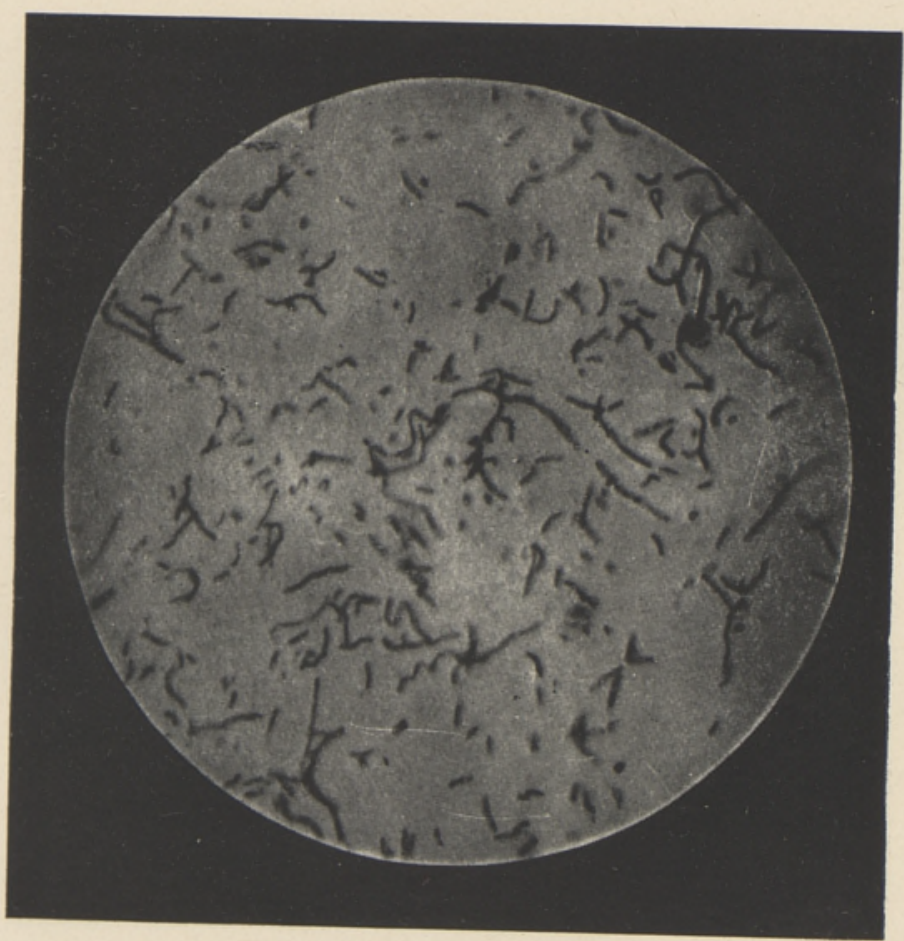
Фото 2. 60-часовая культура Thermobacillus azotofigens.
Увеличение $700 \times$. 


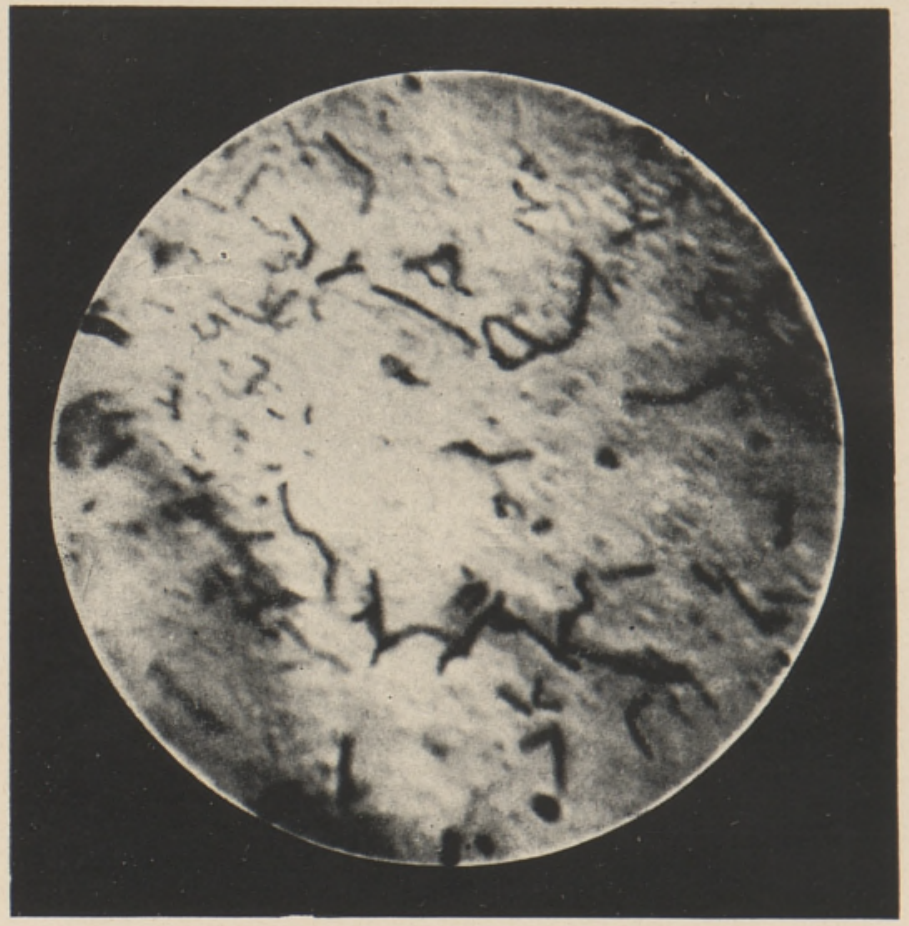

Фото 3. 72-часовая культура Thermobacillus azotofigens. Увеличение $1000 \times$.

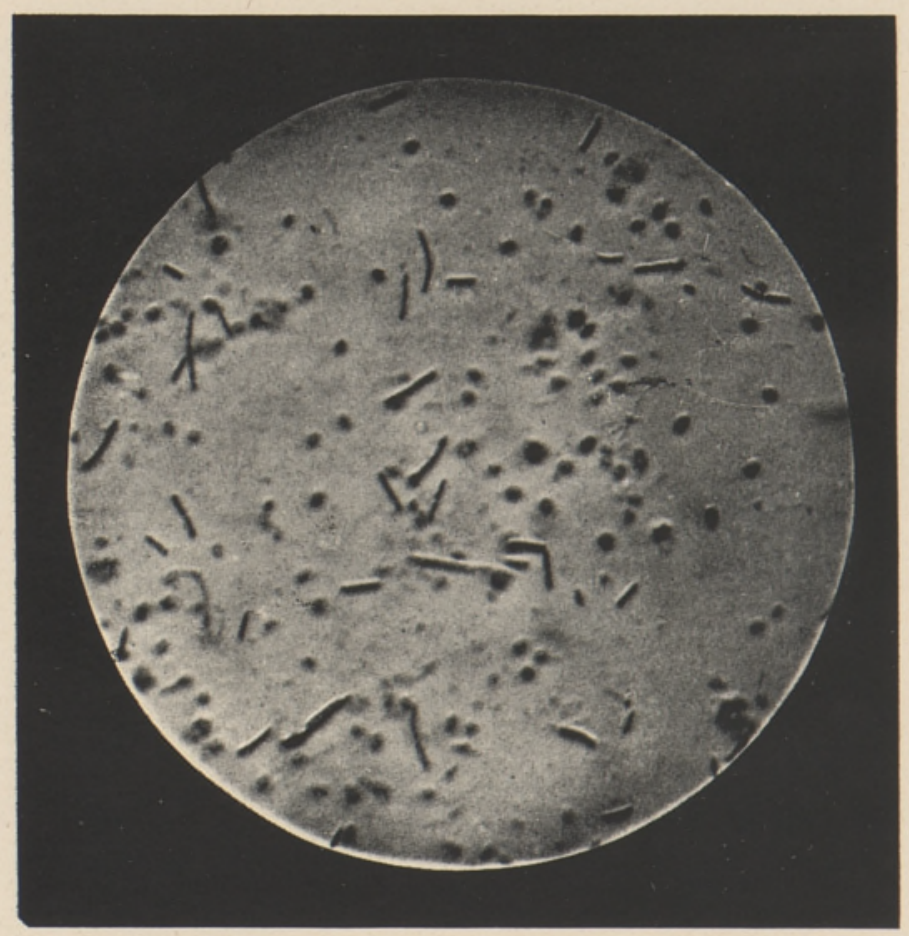

Фото 4. 7-суточная культура Thermobacillus azotofigens. Увеличение $700 \times$ 
Дееятельность Thermobacillus azotofigens Rahno et Tohver sp. $\mathrm{nl}$. несомненно представляет практический интерес, особенно в навозе и компостах, где температура нередко поднимается настолько, что развитие обычных мезофильных азотфиксаторов подавляется полностью. Поэтому мы продолжим исследования этого микроорганизма в направлении установления возможностей его практического использования.

Ннститут растениеводства Академии наук Эстонской ССР
Поступила в редакцию 16 XII 1955

\section{ЛИТЕРАТУРА}

1. Им шенецки й А. А., Микробиологические процессы при высоких, температурах, Изд. АН СССР, 1944.

2. К а а ильников Н. А., Определитель бактерий и актиномицетов, Изд. АН CCCP, 1949.

3. Ми шустин Е. Н., Термофильные микроорганизмы в природе и практике, Изд. AH CCCP, 1950.

4. Alle n M. B., The Thermophilic Aerobic Sporeforming Bacteria, Bact. Rev., 17, 125, 1953.

5. De Kruyff E., Les Bactéries Thermophiles dans les Tropiques, Bull. de Départ. l'Agric. aux Indes Néerlandaises. Microbiol., 4, 30, 1909, Centr. Bakt., 2 Abt., 26, 65 $1910 ; 34,65,1913$.

6. Morrison L. E. and T anner F. W., Studies on the Thermophilic Bacteria, 1. Aerobic Thermophilic Bacteria from Water. Journ. Bact., 7, 343, 1922.

7. Pringsheim H., Uber die Assimilation des Luftstickstoffes durch thermophile Bakterien. Centr. Bakt., 2. Abt., 31, 23, 1911.

\section{ESIALGSEID ANDME̊ID TERMOFIILSEST ÕHULÄMMASTIKU SEONDAJAST THERMOBACILLUS AZOTOFIGENS RAHNO ET TOHVER SP. N.}

\section{TOHVER}

\section{Resümee}

1955. a. kevad-talvel saime Ashby-agaaril $60^{\circ} \mathrm{C}$ juures toimunud inkubatsioonil õhulämmastikku seondava mikroobi arengu. Mikroob eraldati Eesti NSV Harju rajooni I. V. Mitšurini nimelise kolhoosi kamar-karbonaatse põllumulla ülemistest horisontidest. Edasises töös õnnestus koostada mikroobile spetsialalne sööde, millel eraldati puhaskultuur ja teostati selle lämmastikku seondava võime määramised. Söötme koosseis vedelkultuuri slaamiseks on: $\mathrm{K}_{2} \mathrm{HPO}_{4}-0,24 \%, \mathrm{KH}_{2} \mathrm{PO}_{4}-0,01 \%, \mathrm{MgSO}_{4}-0,02 \%$, $\mathrm{NaCl}-0,02 \%$, $\mathrm{FeSO}_{4}$ ja $\mathrm{MnSO}_{4}$ - jäljed, kriit - 0,5\%. Agaarkeskkondade saamiseks tuleb kõiki mineraalsoolasid võtta kahekordses koguses, energeetilist ainet aga mõlemal juhul $0,5-2,0 \%$. Lisaks eelnevaile peab 1 liiter söödet sisaldama $50 \mathrm{ml}$ mullaekstrakti, $10 \mathrm{ml}$ pärmiekstrakti ja $1 \mathrm{ml}$ M. V. F jo d or ov i mikroelementide lahust.

Mikroob, mille nimetasime Thermobacillus azotofigens Rahno et Tohver sp. n., on aeroobne batsill, millel on iseloomulik peen rakukuju mõōtmetega $5-7(10) \times 0,5-1,2 \mu$. $24-48$-tunnistes noortes kultuurides on rakud neis piirides lühemad (foto 1 ), hiljem aga venivad pikaks ja peeneks (fotod 2 ja 3). Mikroobi flagellatsioon on peritrihhaalne, noortes kul- 
tuurides (kuni 120 tundi) on ta liikumisvồimeline. Vanemates kui 4-5-päevastes kultuurides võib mõnikord näha mikroobirakkudest ahelaid.

Söötmetes, mis sisaldavad energeetilise materjalina suhkruid, algab spoori moodustumine neljandal või viiendal inkubatsioonipäeval (foto 4). Spoorid moodustuvad terminaalselt. Ovaalsed spoorid on 1,5-2 korda suurema läbimõõduga kui vegetatiivsed rakud. Mikroob ei moodusta kapsleid.

Gram-reaktsioon on positiivne.

Vedelsöötmeis moodustab mikroob difuusseid limakogumeid. $45-50^{\circ} \mathrm{C}$ juures inkubeerimisel teostab kultuur oma larenemistsükli 8-10 päeva jooksul. Sellest alates on kultuuris juba raske leida vegetatiivseid rakke. Tahkel agaarsöötmel ilmuvad kolooniad pärast 18-24-tunnist lag-fiaasi värvitute limaste tilkadena, mis püsivad inkubatsiooni kolme esimese päeva kestel. Hiljem nad laienevad, kaotavad oma korrapärase kuju ja lōpuks ühinevad limakihina, mis katab Petri kausi põhja.

Mikroob on võimeline energeetilise materjalina kasutama mitmesuguseid süsivesikuid ja orgaaniliste hapete soolasid. Selgus, et suhkrute kasutamisel oli molekulaarset lämmastikku seondav võime $2,80-4,51 \mathrm{mg}$ kasutatud energeetilise materjali grammi kohta.

Mikroob ei arene liha-peptoonkeskkondades ega keskkondades, mis sisaldavad nitraate. Areng ei toimu orgaanilise aineta söötmetes. Tugevaimad kultuurid saime suhkrute (sahharoos, peedisuhkur) kasutamisel. Tuleb eelistada energeetilise aine madalaid kontsentratsioone $(0,5-1,0 \%)$, sest ${ }^{-}$ siis on selle kasutamine täielikum.

Meie söötmel oli mikroobi temperatuuri optimum $45-50^{\circ} \mathrm{C}$ vahel (miinimum on umbes $25^{\circ} \mathrm{C}$, maksimum umbes $65^{\circ} \mathrm{C}$ ). Optimaalne $\mathrm{pH}$ väärtus on umbes 7,5 (min. $\mathrm{pH}=6,5$; maks. $\mathrm{pH}=8,3$ ).

Eesti NSV Teaduste Akadeemia

Taimekasvatuse Instituut

Saabus toimetusse

16. XII 1955

\title{
PRELIMINARY DATA CONCERNING A THERMOPHILIC PRODUCER OF THE FIXATION OF ATMOSPHERIC NITROGEN THERMOBACILLUS AZOTOFIGENS RAHNO ET TOHVER SP. N.
}

\author{
V. TOHVER
}

\section{Summary}

In spring 1955 , cultivating at $60^{\circ} \mathrm{C}$ on Ashby agar we got development of an atmospheric nitrogen fixing microbe. The microbe was isolated from the upper layer of the carbonate field soil of the I. V. Michurin collective farm (Harju district, Estonian SSR). Later we succeeded in composing a special medium for the microbe. Its mineral content for liquid medium is as follows: $\mathrm{K}_{2} \mathrm{HPO}_{4}-0.24$ per cent, $\mathrm{KH}_{2} \mathrm{PO}_{4}-0.01$ per cent, $\mathrm{MgSO}_{4}-$ 0.02 per cent, $\mathrm{NaCl}-0.02$ per cent, $\mathrm{FeSO}_{4}$ and $\mathrm{MnSO}_{4}$ - in negligible quantities, chalk - 0.5 per cent. For agar medium all the mineral salts are to be taken in double quantities. Energetic material is to be added 
$0.5-2.0$ per cent. Presence of soil extract $(50 \mathrm{ml}$ per litre), of yeast extract (10 ml per litre), and of Feodorov solution of microelements* ( $1 \mathrm{ml}$ per litre) is necessary.

Using this medium we isolated the microbe into pure culture. It proved to be an aerobic bacillus that has a characteristically thin cell form $5-7(10) \times 0.5-1.2 \mu$. In cultures of $24-48$ hours the cells are shorter (photo 1) than in ripe cultures (photos 2 and 3 ). The flagellation of the microbe is peritrichal, in young cultures (up to 120 hours) it is capable of movement. Chains of microbes may sometimes be observed in cultures of more than $4-5$ days of age.

In media that contain sugars as energetic material the formation of spores begins on the fourth or fifth day of incubation (photo 4). The sporeforming is terminal. The oval spores are $1.5-2$ times thicker than the vegetative cells. The microbe does not form capsules.

The Gram-reaction is positive.

In liquid medium the microbe gives a diffuse conglomerate of mucus. If incubated at $45-50^{\circ} \mathrm{C}$ the culture completes its cycle in 8-10 days. No more vegetative cells are to be found from that date. On solid agar medium the colonies take the form of unpigmented slimy drops in the course of the first three days of incubation. The drops appear after a lagphase of $18-24$ hours. Later they spread, lose their regular form and at last come together into a layer of mucus that covers the bottom of the Petri dish.

The microbe is able to assimilate various carbohydrates and salts of organic acids as energetic material. When sugars were used ability to fix molecular nitrogen was $2.80-4.51 \mathrm{mg} \mathrm{N}$ per $1 \mathrm{~g}$ of consumed energetic material.

The microbe fails to develop in meat-peptone media, in media that contain nitrates. In the absence of organic energetic material development cannot take place. The most successful cultures are obtained when sugars (sacharose) are used. Low concentrations (0.5-1.0 per cent) of the energetic material are prefenable, as they are more completely assimilated.

The optimum temperature for the microbe in our medium is between $45-50^{\circ} \mathrm{C}$. The minimum temperature is about $25^{\circ} \mathrm{C}$, the maximum about $65^{\circ} \mathrm{C}$. The optimal $\mathrm{pH}$ value is about 7.5 (min. $\mathrm{pH}=6.5$, max. $\mathrm{pH}=8.3$ ).

We propose to name the microbe discovered by us Thermobacillus azotofigens Rahno et Tohver sp. $\mathrm{n}$.

Academy of Sciences of the Estonian SSR,

Received

Institute of Plant Growing

Dec. 16,1955

* $\mathrm{H}_{3} \mathrm{BO}_{3}-5 \mathrm{~g},\left(\mathrm{NH}_{4}\right)_{2} \mathrm{MoO}_{4}-5 \mathrm{~g}, \mathrm{KJ}-0.5 \mathrm{~g}, \mathrm{NaBr}-0.5 \mathrm{~g}, \mathrm{ZnSO}_{4}-0.2 \mathrm{~g}$, $\mathrm{Al}_{2}\left(\mathrm{SO}_{4}\right)_{3}-0.3 \mathrm{~g}$, aq. dest. $-1000 \mathrm{ml}$. 